(52) エネルギー・アナリシスによる水循環システムの評価

EVALUATION OF WATER RECYCLE SYSTEMS BY ENERGY ANALYSIS

松本 重行*, 山本 和夫* Shigeyuki MATSUMOTO*, Kazuo YaMaMOT0*

ABSTRACT; This paper appraised 4 models of water recycle systems in urban area such as wastewater reuse system and rain water usage from the point of view of energy consumption. Input-output analysis was used for the calculation of energy consumption. Not only the direct energy such as electric power and fuel but also the indirect energy used for production of equipments or parts in the water system were taken into consideration. The main results obtained were as follows.

(1) The least energy consumption model was unrecycle model.

(2) The largest energy consumption model was individual recycle model, but in low-densed areas below $90 \sim 150$ households $/ \mathrm{km}^{2}$ it was advantageous than unrecycle model.

(3) The energy consumption of wastewater reuse system was mainly attributed to the distribution system and was about $15 \%$ more than that of waterworks.

(4) Recharge of groundwater by infiltration of rain water was better than on-site rain water usage because FRP water tanks consumed a large amount of energy.

(5) Works such as water treatment or water distribution consumed about $50 \%$ of the maintenance energy in unrecycle model and the rest was considered to be consumed in the business in the works.

(6) From the aspects of the energy consumption, johkaso (on-site domestic wastewater treatment system) was advantageous than sewage works in areas below 196 households $/ \mathrm{km}^{2}$.

KEYWORDS; water recycle system, energy consumption, input-output analysis, energy analysis

\title{
1.はじめに
}

都市の水利用は取水、使用、排出というフローで捉えられることが多かったが、近年それに加えて、下水 処理水の再利用やオンサイトの雨水利用、雨水の地下浸透といった、都市域内に人為的な水循環を作りだす 試みが行なわれるようになってきている。

多様化しつつある水利用システムの比較評価には、主としてコスト面からの検討が用いられることが多い。 例えば中水道や雨水利用に関しては、水道料金との比較による採算性の検討がしばしばなされる。しかし、 公共財としての水のコストは政策的な意味をむちあわせていることがあり、その価值を正確に表していると はいえない部分がある。また、地球環境への影響度や省エネ・省資源度を表す指標を考虑した評価が必要で あるという指摘むなされている"。コスト分析を補完するような視点が必要であろう。

本研究ではそのような指標として、水処理に必要な電力や燃料の投入だけでなく、システムの建設や、補

* 東京大学工学部都市工学科 Department of Urban Engineering, The University of Tokyo 
修、廃棄などに必要とされる間接的なエネルギー消費まで含めたエネルギー投入量の計算を試みた。最適規 模の循環利用形態を見出すことが最終的な目標であるが、その基礎的な検討として4つのモデルを設定し、 比較評価を行なった。また、単位水量供給に要するエネルギー消費量の算出による代替水源の比較、および 人口密度とシステムのエネルギー消費量の関係についてる合せて考察を行なった。

2. 分析手法

2. 1 モデル設定

比較の対象として設定したモデルは、以下の 4 つである。また、各モデルの主な設定諸元を表 1 にまとめ て示す。

(1)一過型モデル

上水道システムと下水道システムの組合わせによる、人為的な循環を行なわない一過型の水利用モデルで ある。東京都における実際の上・下水道事業を想定し、基本データとしてその実績值を使用した。また、後 出の個別循環モデルでは高度処理型合併処理浄化槽をシステムの構成要素として間欠曝気による脱窒を行な うことから、水質に関する条件を揃えるために循環式硝化脱窒法による高度処理施設を付加した。家庭内配 管の諸元については、建築費用皘算用資料2) より木造 2 階建て、延床面皘 36 坪の住宅を想定した值として設 定した。

\section{(2) 広域中水道モデル}

下水処理場において高度処理（凝集沈殿、急速濾過、オゾン処理）を行なった再生水を中水管によって広 域循環させるモデルである。上水道システムの設備容量縮小効果を考慮するとともに、高度処理施設および 中水配管について別途モデル設定を行なった。下水道部分については、一過型モデルの下水道システムと同 じ設定である。

\section{表 1 各モデルの主な設定諸元}

\begin{tabular}{|c|c|}
\hline ル & 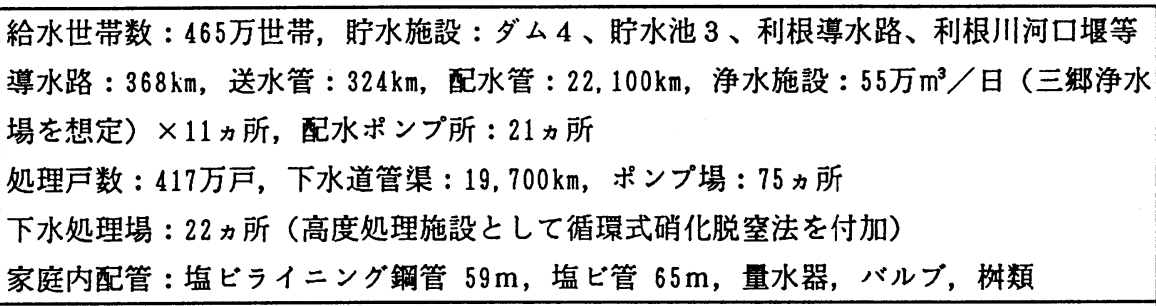 \\
\hline $\begin{array}{l}\text { 広域中 } \\
モ テ ゙ ル ~\end{array}$ & $\begin{array}{l}\text { 上水道システム: 一過型モデル上水道システムの施設容量の } 66 \% \\
\text { 中水道配水池 : 中水配水量を各下水処理場に規模に応じて配分し12時間分の容量を算定 } \\
\text { 中水配管 : 一過型モデル上水道システム配水管断面積の } 34 \%, \\
\text { 家庭内中水配管 : 塩ビライニング鋼管 } 59 \mathrm{~m}\end{array}$ \\
\hline 別行 & 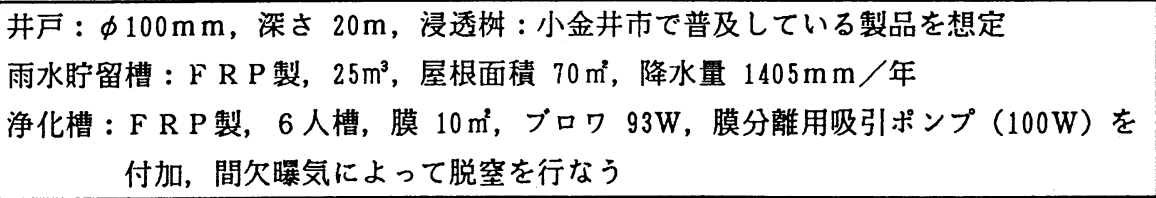 \\
\hline 上水 & 水井： $\phi 310 \mathrm{~mm}$, 深さ $200 \mathrm{~m}, 42$ 本, 取水ポンプ: 揚程 $100 \mathrm{~m}$, 揚水量 $1 \mathrm{~m}^{3} /$ 分, \\
\hline
\end{tabular}


(3) 個別循環モデル

雨水利用、井戸、高度処理型合併処理浄化槽、浄化槽処理水の雑用水利用、および浸透桝の組合わせによ る家庭レベルでの水循環モデルである。高度処理型浄化槽としては、固液分離に膜を使用した浄化槽を考え た。膜分離を用いた浄化槽は、実際の設置例はまだ少ないものの安定して良質な処理水が得られるという技 術的見通し ${ }^{3)}$ が得られている。净化槽の高性能化によって処理水を家庭内で雑用水利用することが可能に なると考えられることから、最小規模の水循環システムとして設定した。また、浄化槽処理水を地下浸透さ せることから、間欠曝気による窒素除去を行なうこととした。

(4) 地下水利用型上水道モデル

高度処理型合併処理浄化槽処理水の地下浸透と、地下水を水源とする小規模な上水道の組合わせによる水 循環モデルである。地下水を媒介とし、自然に存在する水循環を利用する点が特徵である。実際に地下水を 水源とする上水道事業を行なっている東京都武蔵野市の実績値を利用した。また、個別循環モデルと同様に 浄化槽処理水を地下浸透させることから、高度処理型合併処理浄化槽を用いて㗌素除去を行なうこととした。 高度処理型浄化槽と処理水地下浸透施設については個別循環モデルの計算結果を用いた。

上記の各モデルとむ、家庭内の給水配管、排水配管まで含めて計算を行なった。家庭用水、污水のみを対

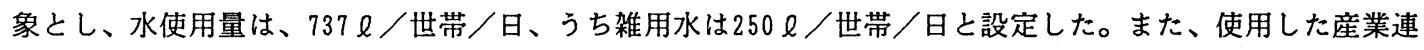
関表の年度に合せて、1988年度（昭和63年度）を対象年度とした。

\section{2 . 2 産業連関分析方式エネルギー・アナリシス}

エネルギー・アナリシスとは、電力や然料の様に直接的な形で投入されるエネルギーだけでなく、部品や 設備を作るのに必要な間接エネルギーまで含めたエネルギー消費量の分析のことで、1970年代以降、農業分 野やエネルギー生産部門を中心として広く用いられている4）。本研究では、モデルの建設、維持管理、廃 棄の全領域を対象とするライフサイクルエネルギーに関して、このエネルギー・アナリシスを試みた。

エネルギー・アナリシスには、積み上げ方式と産業連関方式

の 2 つの方法がある。本研究で用いた後者の方法は、

産業連関表を使用して各産業部門のエネルギー集中度

（単位生産額あたりのエネルギー消費量）を求め、金 額ベースの基礎データをエネルギー消費量に換算する という手法である。産業連関表は、産業を幾つかの部 門に分類し各部門間の製品のやり取りを金額べースで 記述した統計凘料である。よって、ある部門にエネル ギー部門から投入された金額をエネルギ一量に換算す ることによって、その部門の生産額あたりに投入され た直接エネルギー量を計算することができる。本研究 では、産業連関表の統合小分類 (180部門) 表 ${ }^{6)}$ 、及 びエネルギー需給バランス表（カロリーベース）日）

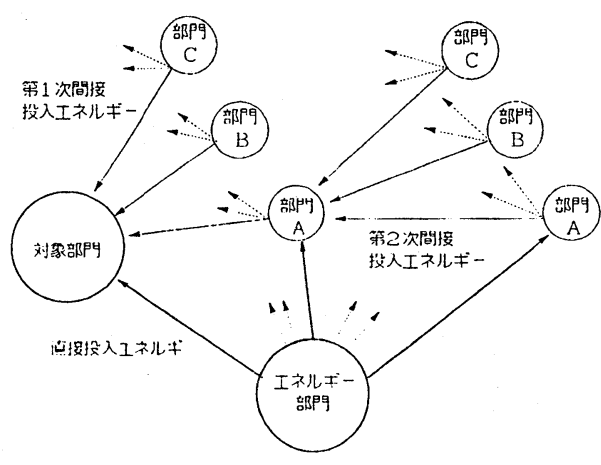

図 1 直接、間接エネルギーの概念 を用いて価格と熱量単位の換算を行なった。ただし電力については、発電時のエネルギー転換口スを考慮し、 2. 250kcal/kWhとして発電量から熱量換算した。エネルギー部門からの直接投入エネルギーの計算には、精 度を高めるために基本分類（列405×行526）表を用い、さらに通産省の統計資料7）を用いてエネルギー部 門からの投入エネルギー量のうら原料として使用された部分を控除した。計算は、第 2 次間接投入エネルギ 一までとした（図1）。 
以上の計算方法によって求め たエネルギー集中度を、表 2 に 示す。なお、表中において上水 道建設と下水道建設が異なる部 門の適用箇所となっているが、 下水道の建設は基本分類 $「 4131$ -02 河川、下水道、その他の公 共事業」に含まれるため「4131 公共事業部門」に、上水道の建 設は工業用水道の建設や土地造 成、ガス関連施設の建設ととも に基本分類 $\lceil 4132-09$ その他の 土木建設」に含まれるため「41 32 その他の土木建設」部門に 属している。また、「5211 水 道」部門には、上水道、簡易水 道、工業用水、下水道の経営

表 2 エネルギー集中度計算例

\begin{tabular}{|c|c|c|c|c|}
\hline 部門名 & $\begin{array}{l}\text { 直接投入 } \\
\text { I神ギ - } \\
\left(10^{7} \mathrm{~kJ} /\right. \\
\text { 百万円) }\end{array}$ & $\begin{array}{l}\text { 間接投入 } \\
\text { I神ギ - } \\
\left(10^{7} \mathrm{~kJ} /\right. \\
\text { 百万円) }\end{array}$ & $\begin{array}{l}\text { I祃 } \\
\text { 集中度 } \\
\left(10^{\top} \mathrm{kJ} /\right. \\
\text { 百万円) } \\
\end{array}$ & 適用箇所の例 \\
\hline ソーダ工業製品 & 22.662 & 11.340 & 34.002 & 塩索 \\
\hline その他の無機化学基礎製品 & 11.175 & 8.888 & 20.063 & 凝集剂 \\
\hline プラスチック製品 & 1.668 & 3.755 & 5.424 & F R P 槽、膜 \\
\hline セメント製品 & 2.227 & 3.489 & 5.716 & 浸透桝、污水桝 \\
\hline その他の一般機械 & 1.279 & 3.729 & 5.009 & ポンプ等機械類 \\
\hline 建設補修 & 1.480 & 2.732 & 4.212 & 補修 \\
\hline 公共事業 & 1.290 & 2.933 & 4.223 & 下水道建設 \\
\hline その他の土木建設 & 1.112 & 3.193 & 4.305 & 上水道建設 \\
\hline 水道 & 7. 286 & 4.076 & 11.362 & 維持管理 \\
\hline
\end{tabular}

関連費用（収益的収支として計上されている費用）が含まれ、建設費用（資本的収支として計上されている 費用）は含まれていない。

\section{2 . 3 エネルギー消費量の計算}

エネルギー集中度を用いて各モデルのエネルギ一消費量を求 める過程を図 2 に示す。

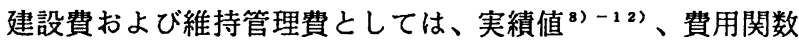
13)、積算用価格 ${ }^{2}$ を使用した。費用関数を用いたのは、管路 建設費原単位、下水処理場およびポンプ場建設費、高度処理施 設建設費および維持管理費である。また、土木工事費デフレー

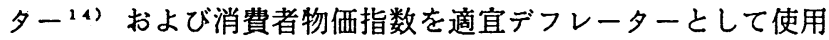
した。償却期間は、実際の事業体で用いられている数值を参考 として定めた。土木施設は $40 \sim 60$ 年、機械設備類は $15 \sim 18$ 年、 家庭内配管、浄化槽等は30年である。家庭用水率、污水率は、 家庭用水、污水のみを計算の対象とするために便宜的に導入し た值で、用途別給水量およびポンプ場揚水量の実䋶值よりそれ ぞれ70.5\%、97.7\%とした。廃棄に要するエネルギーは、家庭 内配管および個別循環モデル設備類に関してのみ建設エネルギ 一の3.1\%として計算した。これは、在来工法による木造住宅 を対象にライフサイクルエネルギーを計算した調查事(例 ${ }^{15)}$ に

実績值もしくは費用関数（円）

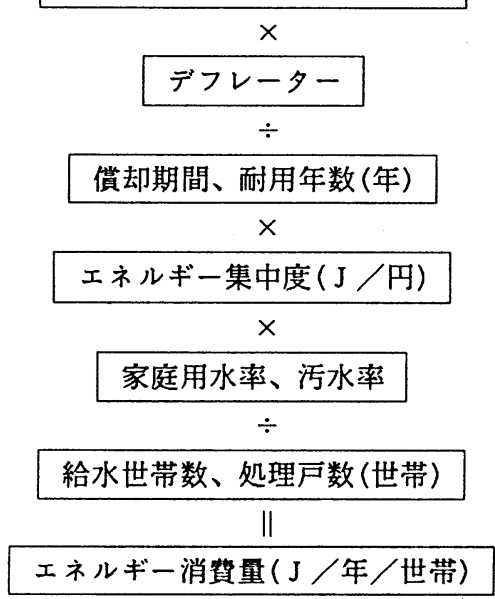

図 2 エネルギー消費量の計算 おいて、解体作業および解体材の輸送に要するエネルギーが建設に要するエネルギーの3.1\%と算出されて いることによる。老朽化し交換した管路の廃棄エネルギーや污泥の輸送に要するエネルギー等は、維持管理 エネルギーに含まれるむのとした。污浔処分場の建設エネルギーは、計算の対象としていない。廃棄エネル ギーの計算結果はきわめて小さい值なので、以下の本文及び図中においては維持管理エネルギーに含めて扱 う。最終的には 1 年 1 世帯あたりの值に揃えて比較した。 


\section{3. 結果および考察}

\section{1 各モデルの比較}

図 3 は、4つのモデルについて計算結果を比較したものである。最すエネルギー消費が少ないのは一過型 モデルであるが、広域中水道モデルのエネルギー消費量す大きな差はない。ただし、広域中水道モデルは上 水道事業の縮小効果を加味しているので、現在既に上水道が普及している地域に中水道を建設する場合は、 この差が大きくなる。一過型モデルのエネルギー消費量のうち、窒素除去のための高度処理が占める割合は $0.24 \%$ にすぎない。

個別循環モデルは、最むエネルギー消費量が多い。これは図 4 に示すように、高度処理型合併処理浄化槽 の消費エネルギーが大きいからである。地下水利用型上水道モデルのエネルギー消費量についても、その 8 割は高度処理型浄化槽によるものである。なお、図中には示していないが、重力分離による従来型の合併処 理浄化槽のエネルギー消費は高度処理型の約 9 割である。これは、主に膜モジュールおよび吸引ポンプの製 造に要するエネルギーが不要になる、建設エネルギー減少効果によるすのである。

また、ランニングェネルギーはほとんどかからないと考えられる雨水利用についてす、F R P 製雨水眝留 槽の製造に必要なエネルギーが大きいということが分かる。貯留槽容積の最適設計の追求や、建物の基礎部 分を眝留槽として利用するなどの工夫が重要であろう。

図 5 は、一過型モデルに関してシステムの建設およびポンプ場や水処理施設における電力使用、薬品使用 による消費エネルギーを示したものである。ダムなどの取水施設、導水施設はエネルギーをほとんど使って

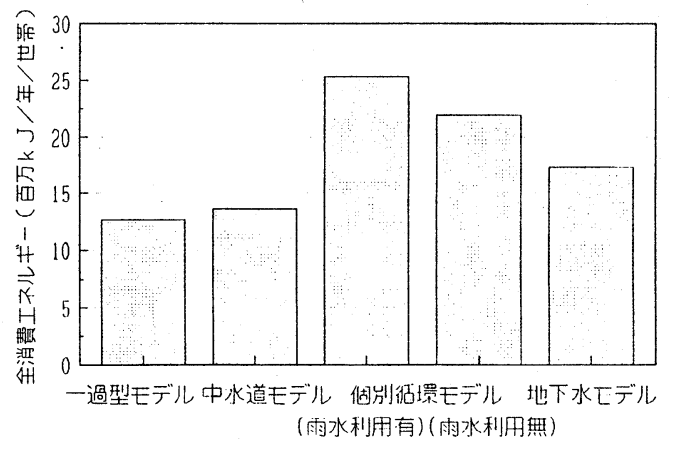

図3各モデルの比較

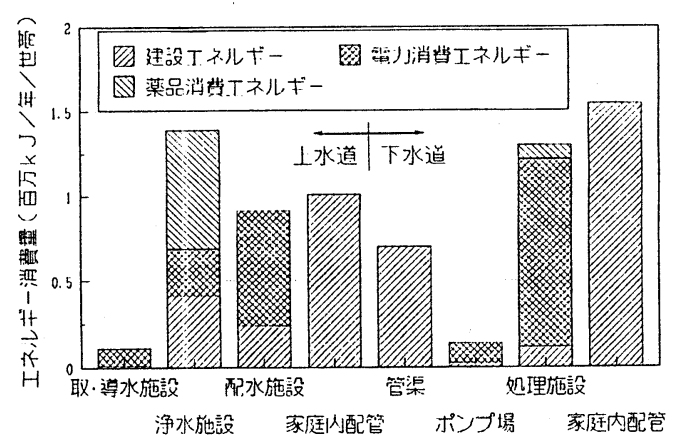

図 5 一過型モデルのエネルギー消費量内訳

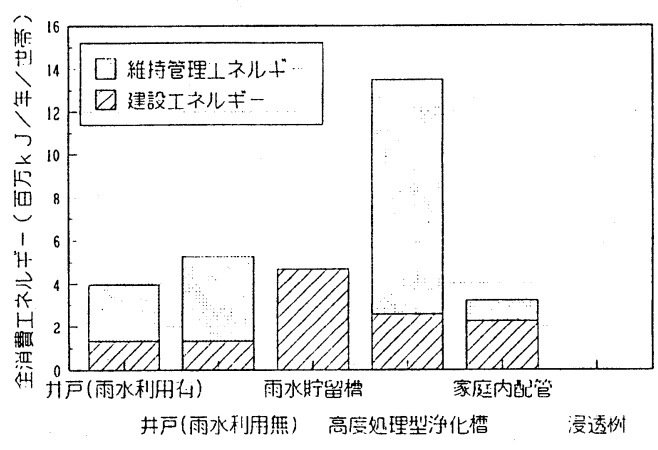

図 4 個別循環モデルのエネルギー消費量内訳

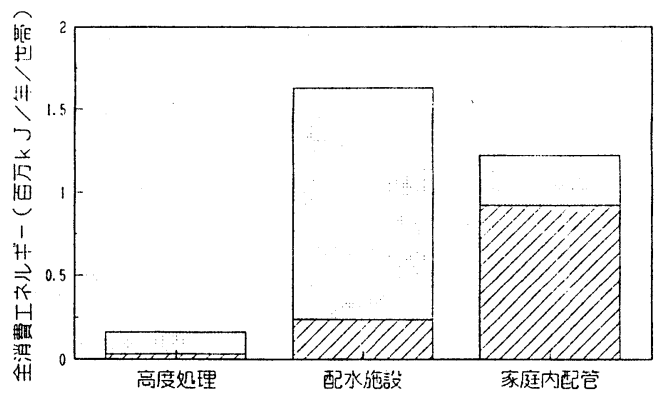

凤建設エネルギー $\square$ 䋛持管理工祀ギー

図 6 中水道システムのエネルギー消費量内訳 
いないこと、および従来あまり検討の対象とされていなかった家庭内の配管に要するエネルギー量が大きい ことが特徵的である。家庭内の配管は、その維持管理にはエネルギーをはとんど消費しないるのの、鋼管や 塩ビ管の製造段階で投入されるエネルギーが多く、1 世帯あたりでは無視できない大きさとなる。

上記の特徵は、近年特に注目を集めている中水道にとってはマイナス要因として働く。図 6 は、高度処理 施設から家庭内中水配管までの中水道システムについてェネルギー消費量を示したものである。エネルギー 消費が配水関係施設に集中していることが分かる。配水施設のうち中水配水管については、共同溝の導入等 によって上水道配水管や下水道管渠と同時に工事を行ない、建設工事に要するエネルギーを隇少させること ができると考えられるが、家庭内配管の建設エネルギーについてはその8 割以上が工法に左右されない材料 エネルギーであることを考え合わせると、二重配管が大きなエネルギー負担になるといえる。このことから、 循環規模や配管容量の最適な設定が重要であるといえよう。また、中水道が脚光を浴びている背景には、ダ ム建設適地の減少、ダム建設による自然やコミュニティの破壊、降水量変動による渴水の危険性といった問 題があるが、エネルギー消費量という観点からは、ダムによる水資源開発に劣る可能性があるといえる。

\section{2 維持管理エネルギーについて}

図 7 は、建設エネルギーと維持管理エネルギーの比率を示したすのである。上・下水道に関しては維持管 理エネルギーが約 7 割を占めて抢り、莫大な設備投資を必要とする社会基盤施設という認識とややずれる結 果となっている。維持管理エネルギーは事業体の年間維持管理費に水道部門のエネルギー集中度を乗じて求 めたすのであるが、そのうち水処理施設や管路、ポンプ施設における電力、薬品、燃料の使用および施設の 補修の 4 項目を別途積み上げ計算することによって説明できる部分は約 5 割であった。残りの半分は、水処 理や集配水などの作業ではなく一般業務に使用されたエネルギーであると思われる。例えば図 8 は、東京都 水道局の光熱水費について費目別の割合を示したものであるが、水道料金の徵収や本庁での事務処理に関わ る経費である業務費、総係費が 8 割以上を占めている。この他、消耗品の使用や金融を始めとする他部門と のやり取りに伴うエネルギー消費す無視できない。巨大な公営企業である上・下水道事業においては、水と いう「商品」の生産に要するエネルギーだけでなく、事業体および関係する他部門を支えるために要するエ ネルギーむ大きいと考えられる。このことから、水循環システムのエネルギー評価を行なう際には、水の流 れのみをみるのではなく、他の社会システムとの相互作用を視野に入れてエネルギー消費構造を捉えていく 必要があると思われる。

また、水道事業に対してエネルギー・アナリシスを適用した最近の研究として、今井らの報告 ${ }^{16) ~ か ゙ あ る 。 ~}$ この報告においては、本研究とは逆にイニシャルエネルギー（本研究では建設エネルギー）がランニングエ ネルギー（本研究では維持管理エネルギー）よりる大きいという結果を得ている。これは、主に 2 つの要因

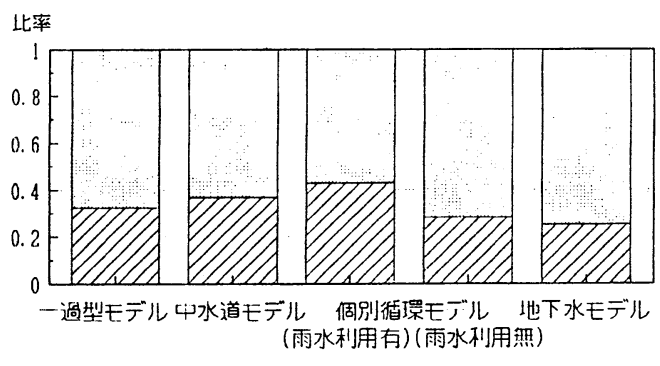

】建設エネルギー $\square$ 維持管㻦丁ネルギー

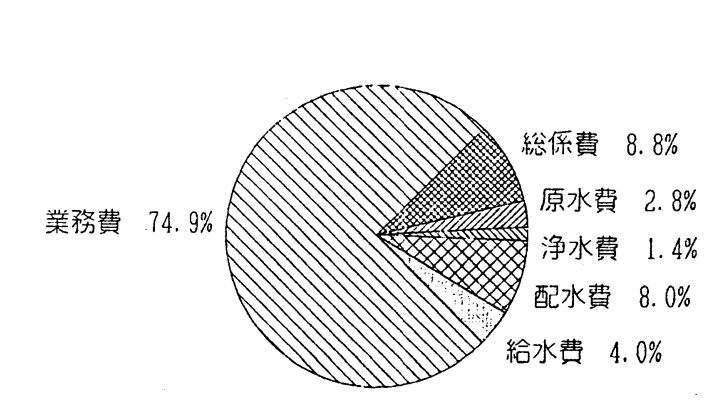

図 8 光熱水費費目別割合
図 7 維持管理エネルギーの割合 
によるあのと思われる。1つは、計算方式の違いである。今井らの論文では、ランニング部分については積 み上げ方式を用いており、取・導水施設、净水場、配水場における電力と薬品の消費、排水処理におけるガ ス、石油の消䏺と污泥の輸送のみを計算の対象としている。すなわち、ランニングエネルギーに関しては、 計算方法之計算対象範囲がいずれも本研究と異なっている。すう 1 つの要因は、モデル設定や用いている原 単位の違いである。イニシャルエネルギーに関しては、本研究と同じ価格換算による方式を用いているが、 想定している建設費や耐用年数、エネルギー集中度、利子加算の有無など、設定している数值に違いがある。 上記の要因はいずれす、計算方法やモデルの設定によって結果がかわってきてしまうというエネルギー・・ アナリシスの手法自体に付随する欠点である。信頼性を高めるために統計類、資料類の整備や方法の統一を 図るとともに、異なる研究に関して結果を比較する際には、対象範囲などの設定や計算方法を明確にする必 要があろう。

\section{3 . 3 代替水源のエネルギー評価}

都市域内の水循環が特に注目されているのは、東京や福岡の様に潜在的な渴水の危険性が高く、従来の方 法による水資源開発が行き詰りをみせている地域である。新規代替水源の確保という政策課題を考える上で の一つの指標として、単位水量あたりのエネルギー消費量の計算を試みた。

比較の対象としたのは、ダムを建設し現在の上水 道を拡張する方法、新たに中水道を建設する方法、 現在下水道や都市下水路で排水されている屋根に降 った雨水む浸透栘に導いて地下浸透させ、地下水を 涵養して上水道の水源とする方法、そして雨水を各 戸眝留して利用する個別型雨水利用の 4 方式である。 結果を図 9 に示す。

広域中水道の水量あたり消費エネルギーは現行上 水道に比べて若干大きく、その差は $4.2 \times 10^{3} \mathrm{k} \mathrm{J} /$ $\mathrm{m}^{3}$ である。これは、ガソリン 0.12 lにあたり、東京

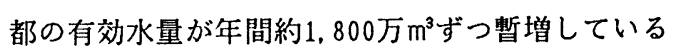
ことを考慮すると、年間 $2,150 \mathrm{k} \ell$ の差となる。こ

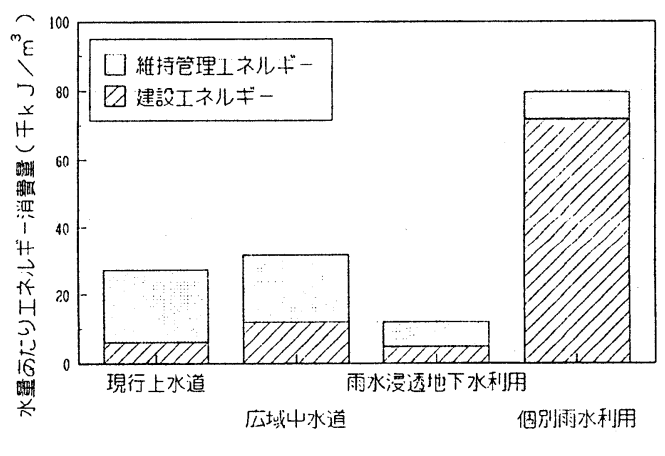

図 9 単位水量あたりエネルギー消費量 れは、東京都の下水処理場で 1 年間に消費されてい る重油の約 1 割にあたる量である。

雨水利用については、F R P 製の貯留槽を新たに設けて個別循環させるよりる、地下に浸透させて地下水 を涵養し、改めて揚水して利用するような循環利用の方がエネルギー的に有利であることが分かる。雨水に よる地下水の涵養は、エネルギー消費が少ないというだけでなく、下水道や都市環境に対するプラスの波及 効果が期待できること、地下水を巨大な雨水貯留槽として利用することができるため設備投資が少なくフレ キシブルなシステムであることなど多くのメリットを持っている。しかし本格的な導入にあたっては、過剩 揚水による地盤沈下や地下水污染の危険性にも充分留意する必要がある。

\section{4世帯密度とエネルギー消費量の関係}

図 3 に示した計算結果では、個別循環モデルよりも一過型モデルの方がエネルギー消費量が少ないという 結果であった。しかし、ここで計算した一過型モデルは東京都を想定したモデル設定であり、人口密度が最 あ大きい地域におけるエネルギー消費量を計算したことになる。そこで、低密度地域における世帯あたりの 管路建設エネルギーの上昇を考虑した計算を行なった。

図10は、配水管の世帯あたり建設費と世帯密度の関係について、水道統計の口径別延長データから求めた 
47都道府県の実䋶値をプロットし、回帰曲線を求めたものである。また、困11は下水道管渠の世帯あたり建 設費と世帯密度の関係について、分流式公共下水道65力所の実績値について同様の作業を行ったものである。 この結果を用いて、世帯密度が変化した時の一過型モデルと個別循環モデルの関係を示したのが図12である。 町営、村営の上水道の平均世帯密度はそれぞれ $155.3 、 86.0$ 世帯 $/ \mathrm{k} \mathrm{m}$ であるから 、管路を引くよりも 個別循環モデルを導入した方がエネルギー的に有利である地域が少なくないといえる。図13は、重力分離に よる従来型の合併処理浄化槽と下水道を比較したものである。両者の有利性が逆転する世帯密度は約196世

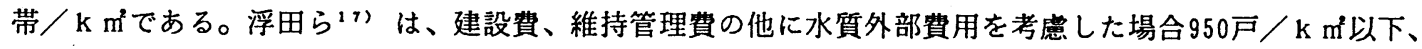
考虑しない場合1,300戸 / $\mathrm{k} \mathrm{m}$ 以下では下水道の方が不利であるという結果を示している。本研究では雨水 排除を計算の対象としていないため単純な比較はできないものの、エネルギー消費量という指標を重視する 立場からは、下水道を整備すべき地域が広くなる可能性がある。

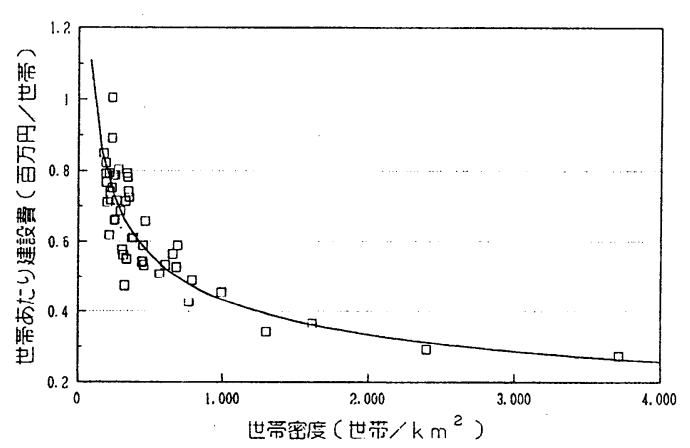

図10 配水管建設費と世帯密度の関係

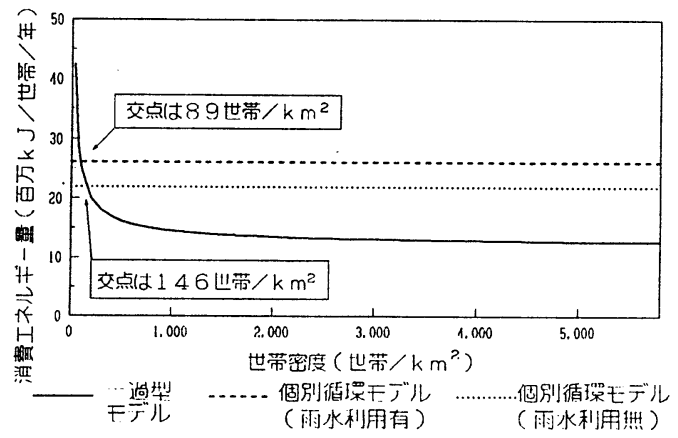

図12 一過型モデルと個別循環モデルの比較

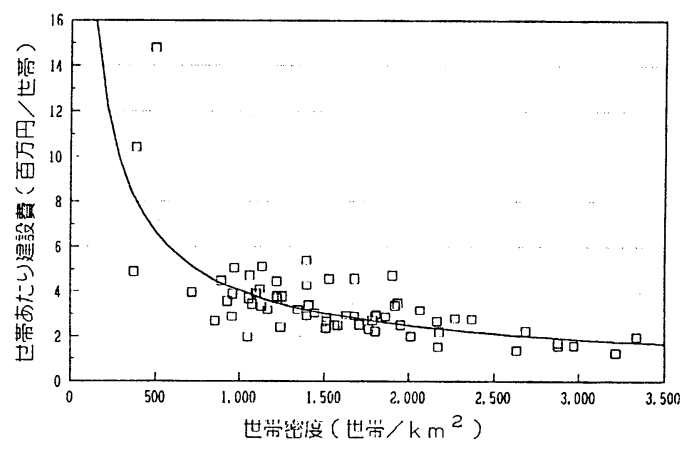

図11 管渠建設費と世帯密度の関係

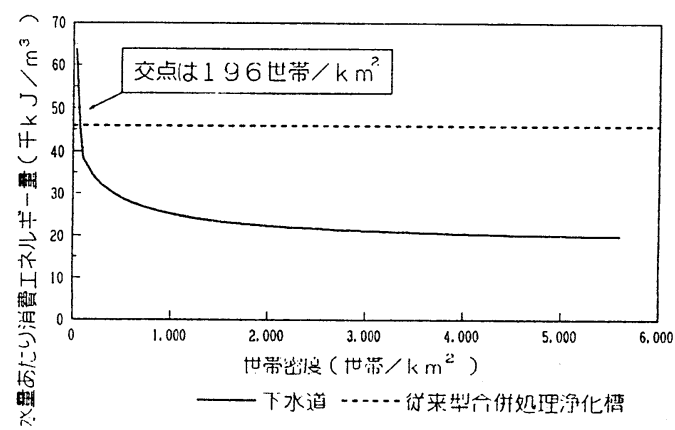

図13 下水道と浄化槽の比較

\section{4. 結論}

本研究では、水循環システムの評価という観点から 4 つのモ゙ルを設定し、適宜諸元を定めた上でエネル ギー消費量の相互比較を行った。間接的に投入されたエネルギーまで含めたライフサイクルエネルギーの計 算によって、配管や F R P 製眝留槽のエネルギー消費量が大きいことが示されるなど、水循環システムを評 価する上での新たな視点を得ることができた。具体的には、以下のような結果を得た。 
（1）４つのモデルのうち、最むエネルギー消費量が少ないのは、循環利用を行わない一過型モデルである。

(2) 個別循環モデルはエネルギー消費量が最も大きいが、世帯密度 90 150世帯 $/ \mathrm{k} \mathrm{m}$ 以下という低密度地 域では、一過型モデルよりも有利になる。

（3）中水道の消費エネルギーは配水部分に集中しており、現行上水道に比べて約15\%大きい。これは、中水 道の導入によって貯水・導水施設が不要となることによるエネルギー節約効果が小さいこと、および二 重配管による消費エネルギーが大きいことによる。

(4) F R P 製雨水貯留槽の建設エネルギーが大きいため、オンサイトの雨水利用よりるいったん地下浸透さ せ地下水を涵養する雨水利用の方がエネルギー消費が少ない。

（5）一過型モデルにおいて、水処理や集配水といった作業によって消費される維持管理エネルギーは約 5 割 であり、残りは事務的業務等において消費されるものと思われる。

(6) 合併処理浄化槽（従来型）と下水道との処理地域の分担についてェネルギー消費量を指標とすると、 196世帯 / $\mathrm{k}$ m²立では浄化槽の方が有利である。

今後の研究方向としては、感度解析によって数值の信頼性、適用範囲を示すととすに、影響力の大きい因 子を抽出し、精度を高めていくことが必要であろう。また、エネルギー消費量を水循環システム最適設計の ための一つの指標として位置付け、その評価に関する統計、資料、方法論等の整備、統一を図るととすに、 あわせて他の指標との関係を分析し、公平かつ総合的な評価手法を確立することが重要であると考える。

\section{参考文献および参考資料}

1) 楠田哲也、森村克美：エネルギーと経済費用見積による下水道の評価，環境システム研究，Vol.20， PP. 270-279, 1992

2) 建設総合調查会 : 積算ポケット手帳（昭和63年度版 設備編），1988

3)C.Chi emchaisri, Y. K. Wong, T. Urase and K. Yamamoto: Organic stabilization and nitrogen removal in membrane separation bioreactor for domestic wastewater treatment, Water Science \& Technology, Vol. 25 No. 10, PP. 231 240, 1992

4)茅陽一編 : エネルギー・アナリシス, 1980,

5)通産省大臣官房調査統計部：産業連関表（1988年延長表），1992

6)資源エネルギー庁編：総合エネルギー統計（平成元年度版），1990，PP. 278-283

7)通産省大臣官房調查統計部：昭和63年石油等消費構造統計表（商鉱工業），1990，PP. 179～227

8) 厚生省監修 : 水道統計（昭和63年度版），1990

9) 東京都水道局 : 事業年報（昭和63年度版），1989

10）（社）日本下水道協会：下水道統計（昭和63年度版），1990

11) 武蔵野市水道部 : 水道事業年報（昭和62年度版），1988

12) 東京都水道局 : 東京都水道事業会計決算書

13）（社）日本下水道協会 : 流域別下水道整備総合計画調查指針と解説，1991

14) 東洋経済新報社 : 昭和国勢総覧下巻, 1980, PP. 255

15)科学技術庁資源調查所：ライフサイクルエネルギーに関する調查研究, 1979, PP. 289〜291

16) 今井茂樹他：水道事業におけるエネルギー消費の分析，水道協会雑誌，第62巻第 4 号，1993，PP. 40〜49

17) 浮田正夫他 : 低密度地域の生活排水処理方式の選択に関する考察, 環境システム研究, Vol.20,1992, PP. $9 \sim 17$ 